\title{
GRIEVANCE PROCEDURES IN NON-UNION FIRMS
}

Alexander J. S. Colvin

Cornell University 


\begin{abstract}
This chapter examines the structure, adoption, usage, and impact of non-union grievance procedures. Non-union grievance procedures vary widely in their structure from informal open door policies to elaborate peer review and arbitration based procedures. Adoption of these procedures is driven by a range of factors including union substation, litigation avoidance, and as part of human resource strategies focused on promoting high commitment from employees. Non-union grievance procedures tend to be used less frequently that their union counterparts, but usage levels vary based on the structure of the procedure with those incorporating nonmanagerial decision-makers exhibiting higher usage levels. Although non-union grievance procedures are often put in place with the goal of enhancing organizational justice, a common problem is retaliation within the organization against grievants who use the procedures.
\end{abstract}

Keywords: non-union grievance procedures, organizational justice, alternative dispute resolution, arbitration, human resource management, employment law 
Grievance Procedures in Non-union Firms, 3

\section{Introduction}

Non-union grievance procedures were often traditionally regarded as a residual category. In examining workplace dispute resolution, the primary historical focus was on the well-established grievance procedures found in unionized workplaces. Even with the increased focus on individual employment rights and declining emphasis on collective bargaining and union representation, the emphasis in dispute resolution has been on the role of the courts and public administrative and adjudicatory agencies. Meanwhile grievance procedures in non-union workplaces, where examined at all, have been relegated to a secondary role as poor copies of their counterparts in unionized workplaces or limited supplements to formal public procedures for enforcing individual employment rights.

Yet these perspectives miss the increasingly central role of non-union grievance procedures in resolving conflicts for employees. For the now 93\% percent of American private sector employees who are not represented by unions, non-union grievance procedures represent the only workplace dispute resolution mechanism potentially available to them (Colvin, 2012). Similarly, although litigation in the public courts is notionally available to all employees, in practice relatively few cases will provide the type of substantive claims and potential damages that can produce a plausible claim to be litigated. For most employees and most workplace disputes, non-union grievance procedures will be the only avenue available to attempt to achieve some redress for unfair treatment in the workplace.

Non-union grievance procedures are characterized by a high degree of diversity in their origins, structures, usage, and impact on the workplace (Westin and Felieu, 1988; Ewing, 1989). Procedures range in type from relatively simple open door policies to elaborate peer review panels with formal jury-like procedures to provide due process. Motivations for their introduction range from efforts to improve management human resource practices to efforts to ward off union organizing drives and protect the organization from lawsuits (Colvin, 2003a). Some non-union grievance procedures are virtually never used by employees whereas others 
are utilized at levels closer to those found in grievance procedures in unionized workplaces. More effective non-union grievance procedures may serve to correct poor management decision-making and enhance employee commitment and retention, yet employees who utilize non-union grievance procedures can also be subject to retaliation and punishment (Lewin, 1990). The role and impact of non-union grievance procedures in the workplace is a complex and varied one, not subject to simple, generalized characterizations as either a panacea or a canard in the search for workplace justice. In examining non-union grievance procedures, the initial focus of this chapter will be on the experience with these procedures in the United States. The reason for this emphasis is that American organizations were the first to adopt these procedures and they are clearly the most widespread and best developed in the U.S. This reflects both the relative weakness of American unions and resulting large non-union sector of the U.S. economy and also the strong role of individual employment rights litigation threats which encourage many American companies to adopt procedures. However, after examining the American experience in this area, I will turn to examining that of other countries, in particularly some of the alternative regulatory approaches affecting procedures found in different countries.

\section{A Typology of Procedures}

What are we talking about when we refer to non-union grievance procedures? An initial problem is to define the boundaries of this phenomenon. Although conflicts arise in all workplaces, in not all is there some type of procedure to resolve these conflicts. In smaller and more informal organizations, conflicts may be handled directly by managers without recourse to any systematic procedure. Instead a manager may use his or her individual discretion to deal with a complaint from an employee or to respond to a conflict that is observed to be occurring in the workplace. This is certainly a form of conflict management, but does not rise to the level of a grievance procedure. If we are simply dealing with managerial discretion in responding to workplace conflict, then we may find one approach being used one day and an entirely different one another. Indeed the manager may choose to respond to one grievance raised by 
an employee and ignore or suppress a different grievance raised by another. As a threshold, the existence of a nonunion grievance procedure implies that the organization has some type of standard, systematic procedure to respond to employee grievances. There may be flexibility in how conflicts are handled and elements of discretion retained by decision-makers, but the key factor is that there needs to be some type of formal procedure through which an employee's grievance can be raised and resolved.

If we start with this relatively basic definition, survey evidence suggests that a majority of American non-union workplaces have some type of grievance procedure (Berenbeim, 1980; Delaney, Lewin, and Ichniowski, 1989; Edelman, 1990; Feuille and Chachere, 1995; Colvin, 2003a). The simplest of these are open door policies, which typically involve a statement of organizational policy so that employees should feel free to bring concerns or complaints to management who will then attempt to address the problem (Feuille and Delaney, 1992; Wheeler, Klaas, and Mahony, 2004; Colvin, Klaas, and Mahony, 2006). Open door policies may specify who complaints can be brought to, often the employee's supervisor, a more senior manager, or a human resources representative. Open door policies may include statements that there will be no retaliation against employees who bring complaints under the policy.

Although many open door policies involve little more than aspirational statements by the organization with little to back them up, some organizations undertake more elaborate efforts to encourage and monitor usage of the open door policy. Perhaps the most extensive system based around this concept is IBM's open door procedure, which dates back to the more informal open door policy followed by the company's Chairman Tom Watson in the 1950s (Ewing, 1989). IBM's modern open door procedure is a formalized investigation procedure, under which employee complaints trigger the rapid deployment of an executive level manager to investigate the conflict and report the results back to the Chairman's office. Although commitment of this level of resources and effort is unusual, open door policies are a widespread feature of American non-union workplaces and may be an important supplement 
to other types of non-union grievance procedures.

Most non-union grievance procedures involve some structure for appeal of an adverse decision against the grieving employee (Feuille and Chachere, 1995; Colvin et al., 2006). A common example would be a disciplinary decision by a supervisor, such as a warning for absenteeism or a suspension for workplace misconduct, that the employee thought was unjustified. Under a typical procedure, the employee can file a grievance seeking to have this disciplinary decision reversed. A central feature of grievance procedures then is who the grievance can be appealed to. In many procedures there are multiple levels or steps of appeal to successively higher level decision-makers. The neutrality and independence of these decision-makers is a central feature determining the degree of due process that the grievance procedure provides. We can classify different types of nonunion grievance procedures by the decision-makers in the procedure and by their degree of independence from the normal management chain of command.

Many basic non-union grievance procedures simply instruct the employee to pursue complaints up the standard chain of command. The first step might involve discussing the concern with the employee's supervisor. The grievance could be pursued further by raising it with the next highest level of manager with supervisory responsibility. The procedure may terminate with an appeal to the plant or facility manager or it may provide that the employee can appeal the grievance to a more senior level executive at the divisional or corporate level. Grievance procedures of this nature have the advantage from the organizational perspective that they respect the existing structure of managerial authority reflected in the chain of command. Lower level decisions may be reversed by higher management, but this is done in the same way that lower level operational decisions can also be reviewed and reversed by higher level decision-makers in the organization. At the same time, this replication of the existing chain of command structure provides the grieving employees with relatively little independence of review in the appeal. The fear will be that higher level managers will have a 
natural tendency to support and affirm the decisions of the subordinates who report to them.

To provide more independent review of grievance and reduce the danger of simply reinforcing the existing decision-making process, some non-union grievance procedures provide for review of complaints by managers outside the direct chain of command above the employee. For example, this may involve a procedure step in which rather than an executive from the employee's own division reviewing the grievance, it is instead reviewed by an executive from another division within the company. Having more senior executives review the grievance in later steps of the procedure may also be directed at achieving a similar goal of removing the decision-making in the review process from the immediate managerial hierarchy of the specific plant or facility involved. In addition to providing a degree of independence from the most closely involved managerial actors, shifting decision-making in the grievance procedure to a higher level in the organization may also serve to provide more focus on the interests of the company as a whole in resolving the conflict. Lower level management may be more likely to be concerned about reaffirming their authority in the workplace and prioritizing the production goals of their specific unit in reviewing grievances. By contrast, higher level management, particularly if not directly connected to the management of the unit where the grievance arose, are more likely to emphasize broader organizational priorities such as ensuring consistency in application of organizational policies and protecting the organization from external threats of litigation or union organizing. These organizational priorities may lead such decision-makers to provide a more rigorous review aimed at ensuring the employee was not treated unfairly.

Management appeals boards provide a procedural structure that emphasizes these objectives of providing review by decision-makers who are higher up in the organization and less directly connected to the management of the specific unit involved in the grievance (Feuille and Chachere, 1995). Under management appeals board procedures, a panel of executives, usually three in number, hears and decides the employee's grievance (Colvin et al., 2006). The executives on the panel will commonly include both operations and human resources managers 
as well as executives both from the grievant's division and from other divisions in the company. Given the relatively elaborate and expensive nature of this step, taking substantial managerial time, it is usually used as a later step in grievance procedures after efforts to resolve the grievance at the workplace level have been unsuccessful. The use of management appeals boards provides grievant with the benefits of multiple decision-makers reviewing the case and the perspectives of managers less directly connected to the situation. Although this provides more independent review than typical non-union grievance procedures, it still involves managers serving as the decision-makers in the procedure. By contrast, to provide greater independence and neutrality in non-union grievance procedures some organizations have adopted procedures that include non-managerial decision-makers.

Peer review procedures are an innovation that employs non-managerial employees from within the organization as decision-makers in the grievance procedure (Colvin, 2003a, 2003b). A peer review panel will commonly consist both of employees who are peers of the grievant and managers, with the peer employees being a majority on the panel (Feuille and Chachere, 1995). A common structure is to have a five-member panel with three peer employees and two managers (Colvin, 2004a). Peer review panel procedures first become wellknown through the example of a GE plant that adopted them in the 1970s in response to a series of union organizing drives. By providing the peer review panels, management at the plant hoped to better respond to employee grievances and convince the workers that they could obtain fair treatment and employee involvement in decision-making through a non-union procedure. Research suggests that peer review panel procedures have been adopted in increasing numbers of organizations in recent decades (Colvin, 2003a).

Arbitration in the workplace dispute resolution arena has been strongly associated with the grievance procedures of unionized workplaces. Final and binding decision-making by independent neutral Labor Arbitrators as the last step of grievance procedures is one of the most long-standing and stable elements of American labor relations. By contrast, until recently arbitration was virtually absent from non-union workplaces. The only exceptions were a small 
number of employers who had introduced arbitration as the final step of their non-union procedures to mimic the union system of labor arbitration and provide a substitute for union representation to guard against organizing drives. The best known example of this is the nonunion grievance procedure at Northrop, which since the late 1940s has featured arbitration as its final step (Westin and Felieu, 1988). Despite the positive experiences of Northrop with this system, the vast majority of non-union employers remained unwilling to turn over decisionmaking authority in their organizations to an independent third-party neutral arbitrator. This aversion to arbitration in the non-union workplace changed dramatically in the 1990s. As will be described in more detail in the section titled "Factors Leading to Procedure Adoption", a shift in the law of arbitration opened up the possibility for employers to use non-union arbitration agreements as a shield against claims being brought against them in the courts. Through the 1990s and 2000s arbitration procedures focused on potential employment law claims spread rapidly, with estimates suggesting around a quarter of non-union employees being covered by them by the early 2000s (Colvin, 2007) and perhaps by a third more at present (Lewin, 2008).

The types of procedures described so far all involve an appeal by the employee to a decision-maker who determines the outcome of the dispute. In these determination type procedures, the employee is presenting a grievance to the decision-maker in hopes of receiving a decision with some type of remedy (Colvin et al., 2006). A separate category of procedures are those that do not involve a determination by a decision-maker, but rather an effort to facilitate a negotiated or consensual resolution of the conflict. The classic example of a facilitation type procedure is mediation. In traditional third-party mediation, an independent neutral mediator attempts to assist the parties to a dispute in reaching a negotiated resolution. Some non-union grievance procedures include mediation as a step, particularly as a prelude to arbitration in procedures that use arbitration as the final step of the procedure (General Accounting Office, 1997; Colvin, 2004a). 
Where effective, these mediation procedures hold the potential for producing faster, cheaper, and more mutually satisfactory resolutions to conflicts than the more formal and involved procedures of arbitration. In addition to formal mediation by outside third-party neutrals, some non-union grievance procedures include internal mediation steps where someone within the organization attempts to mediate the dispute. Human resource managers often do this on an ad hoc basis, but some organizations have attempted to systematize this process by providing structured mediation training and making it a defined step within the grievance procedure. Another approach to internal mediation is the use of peer mediation, where regular employees not specialized in the employment relations function serve as mediators for disputes among their fellow employees (Lipsky, Seeber, and Fincher, 2003). This will often involve a program of training given to employees who volunteer to serve as peer mediators within the organization.

Ombudsperson offices provide a more extended organizational commitment to facilitating conflict resolution in the workplace. An ombudsperson is a designated neutral within the organization tasked with responding to employee concerns and complaints (Kolb, 1987; Bingham and Chachere, 1999). The ombudsperson will not try to determine the outcome of a complaint, but rather uses a range of techniques including information gathering, conciliation, and mediation, to attempt to facilitate a satisfactory resolution of the conflict. An ombudsperson serves as an organizational neutral, situated outside of the standard chain of command and emphasizing confidentiality of complaints received to protect against retaliation toward employees using the office. At the same time, the ombudsperson works within the organization, and successful ombudsmen tend to have significant experience with and knowledge of the organization which allows them to more effectively navigate the internal policies, structures, and politics of the workplace in helping to resolve conflicts. Although many ombudsmen effectively balance these roles, they can cause tensions where a conflict develops into a more formal legal claim against the organization and the ombudsperson's role as a neutral may be compromised by demands to testify in legal proceedings (Cooper, Nolan, and Bales, 2000). Ombudsperson offices are used in a number of larger non-union firms, however, 
the expense of hiring someone into a full-time in-house neutral role makes this type of procedure impractical for small or mid-sized organizations.

\section{Factors Leading to Procedure Adoption}

Why do non-union organizations adopt grievance procedures? In the United States, there is no legal requirement that an employer have any type of internal workplace dispute resolution procedure for employees. In non-union workplaces there is no institutionalized actor like the union pushing for the adoption of procedures in organized workplaces. Nor do nonunion employers receive the benefits of grievance procedures that accrue to their unionized counterparts of having the procedure substitute for the disruptions of direct industrial action or attempts to enforce collective bargaining agreements through the courts. It might be expected that the non-unionized employer would simply rely on the prerogatives of managerial authority and use its own discretion on how to deal with problems in the workplace. Indeed, the continued adherence to the doctrine of employment at-will in American employment would seem to invite this assumption of discretionary authority by management of non-union organizations. Although many organizations do follow this approach, in practice, as we have seen in Section II, most non-union employers do adopt some type of formal grievance procedure. The reasons they do so derive primarily from three major forces or pressures upon management of non-union organizations.

The first force leading to the adoption of non-union grievance procedures is the threat of union organizing. Virtually all American private sector employers would prefer to operate without the constraints of collective bargaining and many take active steps to manage their human resources in such a way as to reduce the likelihood of union organizing (Kochan, Katz, and McKersie, 1994). Union organizing drives often focus on issues of unfair treatment in the workplace and research suggests that campaigns with a justice focus are more likely to be successful (Bronfenbrenner, 1997). A major reason for this is that union organizers can tout the benefits of having a union grievance procedure, culminating in arbitration before a third-party 
neutral, to remedy unfair treatment by management. Whereas non-union employees may be skeptical of promises of enhanced wages or job security, which depend to a large degree on the reactions of management, union organizers can more credibly promise to vigorously represent employees through the grievance procedure, whatever management's reaction.

A non-union employer concerned about the threat of union organizing drive can seek to at least partially substitute for the potential benefits of unionization by adopting a non-union grievance procedure. If employees believe that they can get redress for workplace problems through this procedure, then they will see less need for organizing a union to obtain the benefits of a union grievance procedure. Many early non-union grievance procedures were introduced for exactly this reason (Berenbeim, 1980). The non-union arbitration procedure at Northrop was a notable example, where the strong organizing threat of unions in the aerospace industry led the company to adopt a procedure that closely paralleled union procedures, including the critical final arbitration step (Westin and Felieu, 1988). In practice, most nonunion organizations did not need to go so far in mimicking union grievance procedures to achieve some union substitution effect. Rather, as long as the procedure has some credibility among employees and provides a degree of check on managerial decision-making, it can have the potential to reduce the relative advantage of a union grievance procedure and diminish the strength of the union organizing motivation.

Peer review panel procedures provide a strong example of how employers have adopted more sophisticated union substitution strategies in the design of non-union grievance procedures. A key aspect of justice arguments in union organizing drives is that the union can serve as a check on unilateral management decision-making in the workplace. Peer review procedures address this concern directly by providing non-managerial employees with the majority of votes on the panel deciding grievances. This form of employee involvement in decision-making also has the benefit of avoiding the limitations on employer dominated employee representation schemes in section 8(a)(2) of the US National Labor Relations Act (Colvin, 2003a). Peer review panels are a relatively time and effort intensive procedure for 
dealing with grievances and many managers are reluctant to turn over such important decisionmaking functions to low-level employees (Colvin, 2004a). As a result, research findings suggest that adoption of peer review procedures is more likely in organizations that are subject to stronger union organizing threats, such as in industries like telecommunications and autos, where American unions retain greater strength (Colvin, 2003a).

The second major force leading to the adoption of non-union grievance procedures is the threat of litigation. A key factor in the relatively widespread adoption of non-union grievance procedures in the United States is the unique nature of the American employment law system and the pressures it places on employers. Prospects for employees bringing an employment lawsuit through the American court system are characterized by both relatively low probabilities of success and the chance of relatively large rewards where successful. American employment law continues to be founded on the basic principle of employment atwill under which an employer can terminate an employee for good reason, bad reason, or no reason at all without any obligation to provide prior notice or severance. In order to bring a successful employment lawsuit it is necessary to fall under one of the exceptions to this rule. Courts in most states recognize a limited number of common law exceptions to the at-will rule, such as the public policy exception which has been invoked where the termination violates some strong principle of public policy. In practice, this exception has been limited to unusual situations such as where the employee has been terminated for refusing to commit a crime.

A broader set of exceptions to the at-will rule comes from the various employment statutes enacted by state and federal governments. The prohibitions in the National Labor Relations Act on disciplining or dismissing an employee based on union organizing activity were among the first of these exceptions. The largest category of exceptions in recent years has come from the broad range of anti-discrimination legislation enacted from the 1960s through the present. American anti-discrimination law now bars employment decisions being based on factors such as race, gender, religion, national origin, age, disability, and in some states sexual orientation or smoking. To be successful in the courts, however, it is necessary that employees 
be able to prove that an adverse employment decision was based on one of these prohibited grounds, which is often a challenging task.

The litigation process in the courts can be both time consuming and expensive, with cases on average taking almost two years to get to trial (Eisenberg and Schlanger, 2003). Research suggests that employment discrimination litigation is less likely to be successful at trial than other plaintiffs and more likely to have awards in their favor overturned on appeal (Clermont and Schwab, 2004). Despite these substantial barriers to bringing a claim, employees who are ultimately successful in the American courts can win substantial amounts of damages. A study of employment discrimination cases in the federal courts found a median award amount of $\$ 110,000$ and a mean award of $\$ 301,000$, with a skewed distribution of outcomes including a number of very large awards of over a million dollars (Eisenberg and Schlanger, 2003). Research on employment decisions in the California state courts found an even higher median damage award of $\$ 296,991$ (Oppenheimer, 2003).

The picture that emerges of employment litigation in the United States is of a high risk, high reward system for employees. For organizations facing the threat of litigation, this means that despite the relative employer-favorability of the at-will rule, they are subject to the pressures of a slow-moving, highly uncertain legal process and the risk of a large damage award from the occasional lawsuit that is successful. How do non-union grievance procedures help in this situation? The most direct way in which grievance procedures can prevent lawsuits is by resolving conflicts in the workplace before they can develop into legal cases. This can occur directly through providing the employee with a remedy for unfair treatment in the workplace. It may also occur more indirectly by allowing the employer to identify and deal with problematic managers or policies that could be the potential cause of future lawsuits (Colvin, 2004a).

Another reason that employers may have adopted non-union grievance procedures in response to the expansion of employment laws is the normative influence of the due process models established by the legal system (Edelman, 1990; Sutton, Dobbin, Meyer, and Scott, 
1994; Sutton and Dobbin, 1996). Institutional theory researchers have argued that the uncertainty of the legal environments influenced organizations to adopt procedures that would provide signals of compliance by appearing to provide due process for employees (Edelman, 1990; Edelman, Uggen, and Erlanger, 1999). Professionals in fields such as law and human resource management are argued to have played particularly important roles in structuring and encouraging organizations to conform to these normative influences (Edelman, Abraham, and Erlanger, 1992). Research from this perspective found associations between changes in the employment law environment and the expansion over time of the adoption of non-union grievance procedures (Edelman, 1990; Sutton et al., 1994; Sutton and Dobbin, 1996).

Whereas institutional theory researchers have emphasized the more indirect, normative influences emanating from the employment law environment, in the last two decades the legal system has provided more direct, concrete incentives for the adoption of non-union grievance procedures, particularly for those using arbitration. In a 1991 decision, Gilmer v. Interstate Johnson/Lane, the Supreme Court for the first time held that a legal claim based on an employment statute could be arbitrable under an arbitration agreement. The Gilmer decision held out the possibility to employers of establishing nonunion arbitration procedures for their workforces that would divert legal claims out of the courts and into a private arbitration procedure designated by the employer (Stone, 1999; Colvin, 2003a). In a 2001 decision, Circuit City v. Adams, the Supreme Court confirmed that an arbitration agreement that was part of an employment contract would be enforceable under the Federal Arbitration Act.

The result of these decisions is that an American employer can require its non-union employees to sign an agreement to arbitrate any potential legal claim against the company, including statutory claims such as those under the anti-discrimination laws, as a mandatory term and condition of employment. Based on American arbitration law, decisions by these private employment arbitrators cannot be reviewed by the courts apart from in very narrow 
circumstances such as fraud or misconduct by the arbitrator.

From being a relatively rare phenomenon at the beginning of the 1990s (Feuille and Chachere, 1995), non-union arbitration expanded rapidly in the 1990s and 2000s (Colvin, 2003a; Lewin, 2008) as employers saw it as an opportunity to escape from the risks and uncertainty of the public court system. Research has found that organizations were more likely to adopt non-union arbitration procedures where they were more exposed to potential litigation threats (Colvin, 2003a). An interesting side effect of the expansion of non-union arbitration is that many employers used the occasion of introducing arbitration as an opportunity to review and upgrade other aspects of their non-union grievance procedures (Colvin, 2004a). The result is that the shift in the law of arbitration had an indirect effect of producing a more general expansion of grievance procedures.

Union organizing and litigation threats represent external forces exerting pressure on organizations. In addition to these external factors, organizations also adopt non-union grievance procedures based on internal considerations related to their human resource strategies. Driving these internal motivations is the idea that enhancing fair treatment of employees will produce tangible benefits for the organization.

One major research perspective suggesting the value of adopting non-union grievance procedure is organizational justice theory. Organizational justice theory argues that the degree to which employees perceive organizational decisions as either having or lacking justice will affect important attitudinal and behavioral outcomes. Justice theory argues that there are multiple dimensions of justice perceptions, including procedural, distributive, and interpersonal justice (Colquitt, 2001). The identification of the importance of procedural justice perceptions has particular relevance to the adoption of non-union grievance procedures, since they provide mechanisms specifically designed to provide employees with enhanced procedural fairness in challenging organizational decisions (Sheppard, Lewicki, and Minton, 1992; Folger and Cropanzano, 1998). In a relatively direct test of this premise, Olson-Buchanan (1996) conducted 
an experimental study in which she found that availability of access to a grievance procedure that enhanced procedural justice increased employee willingness to continue working for the organization.

Another theoretical perspective supporting internal organizational motivations for adopting procedures is exit-voice theory, originally developed by Hirschman (1970) and most famously adapted to the labor relations setting by Freeman and Medoff (1984). Exit-voice theory argues that when confronted with deterioration in their employment situation, employees have two potential options: exit, usually involving quitting; and voice, giving expression to the dissatisfaction in hopes of remedying the situation. To the degree that voice options are enhanced, use of exit will be decreased, thereby saving the employer such costs of turnover as loss of existing employee skills and experience and the need to recruit, select, and train new employees. In their formulation, Freeman and Medoff primarily focused on the voice function of unions, but also acknowledged that non-union grievance procedures could potentially provide a similar voice function. Subsequent research on employee turnover in the telecommunications industry evidence found that in addition to the well-established exit-voice relationship in unionized workplaces, non-union grievance procedures in the form of peer review panels were also associated with lower quit rates (Batt, Colvin, and Keefe, 2002).

The degree to which organizations adopt non-union grievance procedures in order to enhance employee commitment and reduce turnover is likely to depend on the overall human resource strategy followed by the organization. Human resource strategies premised on fostering high levels of employee skill, commitment, and participation in the workplace depend to a greater degree on having a relatively stable, experienced workforce and are more likely to be undermined by employee perceptions of injustice in organizational decision-making. Some studies have found positive associations between high performance or high commitment work systems and the adoption of non-union grievance procedures (Huselid, 1995; Colvin, 2004b). The nature of the work system may also influence the structure of the grievance procedure that is adopted, such as a positive association between the use of self-managed work teams and the 
adoption of peer review procedures which similarly rely on group employee involvement in decision-making (Colvin, 2003a).

\section{Procedure Usage}

What do we know about how non-union grievance procedures operate? There is a surprisingly small body of research that has attempted to answer these questions. One reason for the limited extent of research in this area is the difficulty in gaining access to organizations to gather data on what are from an employer's perspective private, internal procedures. Although understandable from an employer's viewpoint, this private structure for dispute resolution is more problematic from a public policy perspective when we consider that among the conflicts resolved through these procedures are disputes over workplace discrimination, sexual harassment, and other issues that implicate public statutory rights. The result of the difficulties in gaining access to organizations to conduct research in this area is that we may be seeing a biased sample in which companies that operate procedures feature relatively high degrees of fairness, and due process protections are more willing to provide access to researchers. This could create a more positive picture of procedures than would be reflected in a more comprehensive sample of organizations. With that proviso in mind, what does the existing research tell us?

Some of the earliest systematic research on non-union grievance procedures was conducted by David Lewin in the 1980s. Lewin (1987) gathered data on the operation of procedures in a set of non-union organizations that had relatively well-developed formal processes for dispute resolution. The companies Lewin examined all had multi-step procedures featuring appeals to successively higher levels of management, but differed in the final step of the procedure with one company having the VP of HR as the final decision-maker, another with the CEO as the final step, and a third with arbitration by an outside third-party neutral as the final step. 
The findings of this study indicated both commonalities and differences across organizations. Grievance rates were relatively similar across the companies-around 4-6 grievances annually per 100 employees, a rate about half of that found in typical American unionized workplaces. Rates of appeal dropped with each successive step in the procedures, with few grievances going beyond the second step involving review by a midlevel functional or HR manager. Among grievances that did proceed farther, the highest appeal rate to the final step was in the company which used arbitration as its last stage, which had an average of 0.4 grievances going to the final step annually per 100 employees compared to an average of only 0.1 final step grievances in the other companies (Lewin, 1987). This finding suggests that the use of third-party decision makers in the procedure may have a substantial effect in encouraging usage by employees.

In addition to the question of grievance rates, Lewin also examined employee win rates in these procedures. A striking finding was that win rates were relatively similar across all companies and steps of the procedures. Employee win rates ranged from $40-50 \%$ of grievances in all three companies in the first three steps of the procedures (Lewin, 1987). Employee win rates did go up to $50-65 \%$ in the final step of each of the procedures, but overall the noteworthy finding is the similarity of outcomes. One explanation that may account for this finding is that employees are rational actors in deciding to file a grievance and managers are likewise rational in deciding whether to resolve a matter before the next step in the procedure. Employees may be reluctant to file grievances where they have relatively low chances of winning, either out of unwillingness to expend the effort of pursuing a grievance or out of fear of retaliation from managers for becoming a troublemaker. Conversely in situations where the employee has a relatively strong grievance with a high probability of success, then managers will have a greater incentive to resolve the matter informally before it consumes time and creates embarrassment by becoming a formal grievance. The result is the grievances most likely to be pursued are those in the middle, where there is some prospect of success but not a high certainty that the employee will be successful. This prediction corresponds to the finding of 
mid-range employee win rates.

In a subsequent study, I investigated the question of whether use of non-managerial decision-makers in procedures affected usage and outcomes across a broader sample of organizations (Colvin, 2003b). In a sample of 180 establishments in the telecommunications industry, I found that that grievance rates were significantly higher in non-union procedures that included either arbitration or peer review. Whereas the annual rate of grievances of disciplinary decisions was only 1.3 per 100 employees under procedures with managerial decision-makers, the rate was 2.9 per 100 employees under peer review procedures, and 3.2 per 100 employees under procedures with arbitration as the final step (Colvin, 2003b). To account for variation in the underlying level of workplace conflict, I also calculated the percentage of all disciplinary decisions that were appealed. The results were similar, with $11 \%$ of disciplinary decisions being grieved under procedures with managerial decision-makers, $30 \%$ of decisions being grieved under peer review procedures, and $34 \%$ being grieved under procedures with arbitration as the final step (Colvin, 2003b). As suggested by Lewin's findings, employee win rates did not much vary by type of procedure, averaging 30-45\%; however, the influence of the nature of the procedure on the likelihood of appealing a decision made a bigger difference. Overall in establishments that had only managerial decision-makers in their procedures, on average only $2.7 \%$ of disciplinary decisions were successfully reversed through filing grievances. By contrast, 9.9\% of disciplinary decisions were successfully appealed under peer review procedures and $11.1 \%$ under procedures with arbitration as the final step (Colvin, 2003b). These differences indicate that employees are more willing to bring grievances where the procedures provide the due process protection of nonmanagerial decision-makers and this ultimately produces more cases in which the employee is successfully able to achieve a change in the decision being challenged.

Procedure structure is only part of what determines usage of non-union grievance procedures. Another important factor is the nature of the workplace employment system. Organizations with work and human resource systems that invest more heavily in employees 
and provide employees with greater involvement in workplace decision making are more likely to provide employees with more effective grievance procedures and reduced levels of workplace conflict (Colvin, 2004a). In a recent study, I examined the impact of variation in the structure of procedures and in the nature of work and human resource systems on workplace dispute resolution outcomes (Colvin, 2013). Establishments that had non-union grievance procedures with more due process protections, including steps with non-managerial decisionmakers, had higher employee grievance rates and a greater likelihood of appealing disciplinary decisions. However, the use of high involvement work systems, including employee participation systems such as teams and high levels of employee training and skills, had an even stronger impact on workplace dispute resolution, including associations with greater due process protections in procedures, reduced levels of workplace conflict, and lower grievance rates. There is an element of complementarity in these findings. Ideally, employees should prefer effective grievance procedures that they do not need to use too frequently due to fewer adverse decisions in the workplace. The combination of high involvement work systems that reduce underlying levels of conflict, and non-union grievance procedures with stronger due process protections that are more effective at resolving conflicts that do arise, appear to provide this desirable combination of circumstances.

\section{Impacts on Employees and the Workplace}

So far the discussion has focused on how non-union grievance procedures operate in different organizations. But what does research tell us about the individual employee experience of using non-union grievance procedures?

Organizational justice theory suggests that to the degree that non-union grievance procedures enhance perceptions of justice in the workplace, we should see positive individual level attitudinal and behavioral responses from employees (Sheppard et al., 1992; Folger and Cropanzano, 1998). Research in this area has divided employee justice perceptions into separate constructs measuring perceptions of procedural justice, distributive justice, and 
interpersonal justice (Colquitt, 2001). An important finding from this line of research is the greater importance of procedural justice perceptions over distributive justice perceptions in shaping attitudinal and behavioral outcomes. For grievance procedures, the implication is that we should anticipate that to the degree they provide enhanced procedural fairness in workplace decisions, they should produce positive outcomes beyond the degree to which they produce decisions favorable to employee grievants. The organizational justice theory-based propositions about the positive effects of non-union grievance procedures were tested in an experimental study by Olson-Buchanan (1996). She found that subjects who were given access to a grievance procedure were more likely to be willing to continue working for the organization.

Exit-voice theory provides similar predictions of positive effects from the adoption of nonunion grievance procedures. More specifically, exit-voice theory suggests that greater availability of voice options to remedy dissatisfaction with conditions should lead to reduced recourse to the exit option (Hirschman, 1970). In the workplace context, the classic example of this was the finding that the availability of the voice mechanism of union representation and grievance procedures was associated with lower rates of exit as seen in voluntary turnover or quit rates (Freeman and Medoff, 1984; Batt et al., 2002). The direct applicability of this to grievance procedures was shown in a study by Rees (1991) which found that teacher quit rates were lower in school districts where the union contracts included stronger grievance procedures. Relatively little research has tested this proposition in the non-union setting. One study that tested it in the telecommunications industry found some weak evidence that nonunion peer review procedures are associated with lower quit rates, but no evidence for other types of nonunion grievance procedure (Batt et al., 2002).

A darker perspective on the workplace impact of non-union grievance procedures is suggested by research looking at retaliation against employees who use these procedures. $\mathrm{A}$ number of studies of unionized workplaces have found that employees who file grievances are subject to lower performance evaluations, greater likelihood of subsequent exit from the 
organization, and other negative outcomes (Klaas and DeNisi, 1989; Boroff and Lewin, 1997; Lewin and Peterson, 1999). Similarly, in the non-union sector, Lewin (1990) found that in an organization with a non-union grievance procedure, employees who filed grievances were more likely to have negative performance evaluations in subsequent years. If these negative outcomes reflect retaliation against the employee for using the grievance procedure, then this has the potential to undermine the effectiveness of the procedure and discourage future use. However, it is difficult for research to identify the degree to which negative outcomes for grievance filers reflect actual retaliation or a post-grievance deterioration in the employee's performance, or commitment to the organization. By contrast, in a study that controlled for the perceived mistreatment experienced by the employee, Boswell and Olson-Buchanan (2004) found that grievance filers did not have significantly worse exit and neglect related attitudes and intentions. While further research on this question would be valuable, it is clear that the potential for retribution is a danger for non-union grievance procedures and one that it would be well advised for organizations to guard against.

\section{Cross-National Variation in Non-Union Grievance Procedures}

So far the discussion has focused on research on non-union grievance procedures in the United States. This reflects in part the reality of the large non-union sector of the American workforce and the high degree of experimentation and innovation by American organizations in this area. The result is that the major body of the research on this topic has used American organizations as its setting. However, many other countries now have sizable and growing numbers of workers who are not represented by unions.

What do we know about grievance procedures for these non-union workers outside of the United States? Non-union grievance procedures have not been a major phenomenon in the coordinated market economies (Hall and Soskice, 2001), such as Germany, France, and most of continental Europe. In particular, nations where collective bargaining is centralized and contract coverage extended to most of the workforce lack the defined non-union sector that has been 
the center of innovation in grievance procedures. In addition, many of these countries have public employment dispute resolution procedures that are used with much higher frequency by workers than the more complex and expensive American litigation system. For example, in Germany and France, the percentage of the workforce submitting an employment claim through their respective public procedures was $1.5 \%$ and $0.7 \%$ in 2002 respectively (Gibbons, 2007). By contrast, in the liberal market economies, particularly the Anglo-American countries, the large and growing non-union sector has seen greater variation and innovation in employment relations practices including non-union grievance procedures (Colvin and Darbishire, 2012).

Among the liberal market economies, Canada provides the closest comparator to the United States given the two nations' high levels of economic and cultural integration. A long line of research has noted that, despite these similarities, the relatively more labor favorable legal regime in Canada has produced a much higher union representation rate of just under $30 \%$, compared to around $12 \%$ in the United States (Godard, 2003). However, this still means that over $70 \%$ of the Canadian workforce is in the non-union sector. Non-union grievance procedures are widespread in Canada as in the United States. In a comparative study of organizations in the American state of Pennsylvania and the Canadian province of Ontario, I found that while $60 \%$ of American organizations had adopted non-union grievance procedures, some $46 \%$ of Canadian organizations had also adopted non-union grievance procedures (Colvin, 2006). Interestingly, despite Canada following a just cause standard for dismissals compared to the American employment at will rule, the higher adoption rate for non-union grievance procedures in the United States was in part a result of greater concerns about litigation among the American organizations. What this likely reflects is the greater uncertainty and risk created by the high damages and variability of outcomes in the American litigation system compared to a more employee favorable but relatively predictable employment law regime in Canada (Colvin, 2006). Among Canadian organizations, the predictors of non-union grievance procedure presence are similar to those found in the United States. Analysis of data from the Canadian Workplace and Employee Survey (WES) showed that presence of non-union grievance 
procedures was associated with the use of high involvement work organization practices (Colvin, 2004b).

Other liberal market economies have substantial non-union sectors, but it is not evident that patterns of development of procedures parallel the North American experience. A survey of non-union multinationals in the Republic of Ireland found that almost all had some type of formal conflict management procedures, but relatively few of these companies used more advanced ADR procedures such as arbitration, peer review, or ombudspersons (Doherty and Teague, 2011). Relatedly, in a study of Irish commercial enterprises, Roche and Teague (2012) found that innovations in ADR procedures were more likely where unions were recognized as compared to non-union settings. This was true for individually focused ADR procedures, such as using review panels or external experts to resolve grievances and group focused ADR procedures such as assisted negotiations and external arbitrators. The one exception to this pattern was that brainstorming problem solving procedures were more common in non-union enterprises. Overall however, Roche and Teague conclude that "[i]n the USA, firms adopting ADR inspired conflict management practices are doing so to address individual-based disputes and grievances, and as part of more general union substitution strategies, whereas in Ireland innovating firms tend more commonly to be unionized and are focusing on group based conflict management" (2012: 545).

Evidence from the United Kingdom suggests that the expansion of non-union Workplaces in that country is producing a shift in the mode of expression of conflict. Analyzing data from the 2004 Workplace Employment Relations Survey, Dix, Sisson, and Forth (2009) find that while rates of industrial action are much lower in non-union workplaces, claims to employment tribunals are higher where there are non-union voice mechanisms or no voice mechanism than where there are union voice mechanisms in the workplace. Interestingly in their results, the proportion of workplace with non-union voice mechanisms experiencing grievances was relatively similar to the proportion of workplaces with union voice mechanisms 
with grievances, $40 \%$ versus $45 \%$ respectively (Dix et al., 2009).

At the level of public policy, the United Kingdom undertook a more direct approach to encouraging the expansion of workplace grievance procedures with the enactment of a statutory dispute resolution procedure in 2004 . The 2004 Act required organizations to follow a three-step procedure for discipline and workplace grievances, involving: the disciplinary decision or grievance being put in writing; a meeting being held to discuss the issue; and a procedure for the employee to appeal the decision (Harris, Tuckman, and Snook, 2012). Failure to follow the statutory grievance procedure would result in a dismissal being presumed to be unfair, and failure of the employee to first pursue the claim through the procedure would result in the subsequent dismissal of an employment tribunal claim. Problems with excessive formalization of processes and an emphasis on procedure over the substance of employment claims quickly led to pressure on the British government to revisit the statutory procedure requirement, which appointed an independent review commission (Harris et al., 2012). This resulted in the Gibbons (2007) report, which recommended the repeal of the statutory grievance procedure requirement. The statutory procedure provisions were repealed in 2009 and replaced by a more flexible approach in which the Advisory, Conciliation and Arbitration Service (ACAS) developed a new Code of Practice on Disciplinary and Grievance Procedures to serve as guidelines for organizations but without the previous preclusive effect on claims. As yet it is unclear what the effect of these shifts in public policy has had on the incidence of grievance procedures in the UK, particularly in workplaces where unions are not recognized.

\section{Conclusion}

When we survey the landscape of employment relations, it is clear that non-union grievance procedures have become an important institution in the workplace. Most notably in the United States, with its largely non-union labor force, non-union grievance procedures are the primary structure for most employees for addressing conflict in the workplace. Although still limited in extent, current research in this area allows us to identify some key features of 
this phenomenon. First, non-union grievance procedures are characterized by a high degree of diversity in their incidence, origins, structure, and operations. Rather than a uniform system of conflict management of the type we see in union grievance procedures or public dispute resolution systems, non-union grievance procedures are idiosyncratic to the individual organization and vary widely in their key features. Much as we have seen growing variation in patterns of human resource practices between organizations and widening income inequality across the economy, so also in the rise of non-union grievance procedures are we seeing rising inequality in access to justice in the workplace.

Second, research indicates that the nature of non-union grievance procedures matters for important employee and workplace outcomes. Many non-union grievance procedures are relatively simple structures with only managerial decision-makers and low levels of usage by employees. But we have also seen the expansion of procedures that use nonmanagerial decision-makers, such as peer review panels and outside neutral mediators and arbitrators, and these procedures are used more frequently by employees with greater levels of success in challenging workplace decisions. Third, non-union grievance procedures do not exist in isolation within the organization. Research in the United States has shown that the expansion and quality of non-union grievance procedures are highly influenced by the nature of external institutional pressures from the legal system and from union organizing threats. Looking across countries, the public policy environment is a key determinant of whether or not non-union grievance procedures are likely to develop as a significant phenomenon in nations other than the United States.

What are the important unanswered questions about non-union grievance procedures? One of the most significant is the basic question of what is the distribution of procedures. Research in the United States suggests that more than half of non-union organizations have some type of formal procedure and that there is wide variation in the nature and structure of these procedures. However, we lack good data on the exact distribution of different types of procedures and how this distribution has changed over time. Data on non-union grievance 
procedures from other countries are generally even more limited. Systematic national level survey data would allow us to understand the incidence and structure of procedures, as well as to investigate further questions such as the factors that determine the types of procedures that are adopted.

A second area in need of further research is the question of what impacts non-union grievance procedures have in the workplace. Research suggests some positive impacts in the ability of employees to challenge unfair decisions and in the enhancement of organizational justice perceptions. However, among the most troubling of existing research findings is Lewin's (1990) identification of retaliation against both grievance filers and supervisors of grievants. It suggests the importance of identifying how frequent is retaliation and what factors lead to retaliation or what policies or practices might be effective in preventing retaliation. Furthermore, we know little about the potential indirect effect of non-union grievance procedures in the workplace. Does the potential for having their decisions reviewed through procedures cause managers to be more careful and prudent in their workplace decisionmaking? Do employees engage in positive workplace behaviors because they perceive that nonunion grievance procedures protect them from unfair adverse decisions?

Last, relatively little attention has been paid to the question of representation in Nonunion grievance procedures. One of the main contrasts to grievance procedures in (p. 186) unionized workplaces, where the union provides employees with an institutional structure for representation, is that in non-union procedures the employee is typically unrepresented. He or she must file and present the grievance on his or her own. This may be a daunting task for many employees and hinder effective use of the procedure. Although notionally an employee might hire an attorney to provide representation, in practice this is likely to be prohibitively expensive and management may not allow an outside representative to participate in the process. In some organizations, human resource managers may serve as representatives of employee grievance and partially fill this gap (Colvin, 2004a). However, this creates a natural conflict of interests since they remain employees of the company and so this may only be effective where 
the issues involved are more lateral conflicts in the workplace and do not implicate hierarchical conflicts with the employer or external rights. More broadly, the question of how to provide effective representation for non-union employees is one that challenges both the operation of non-union grievance procedures and that of employment relations more generally in the nonunion workplace.

\section{REFERENCES}

Batt, R., Colvin, A., and Keefe, J. 2002. “Employee Voice, Human Resource Practices, and Quit Rates: Evidence from the Telecommunications Industry." Industrial and Labor Relations Review, 55(4): 573-94.

Berenbeim, R. 1980. Nonunion Complaint Systems: A Corporate Appraisal. New York: The Conference Board.

Bingham, L. B. and Chachere, D. R. 1999. “Dispute Resolution in Employment: The Need for Research." In E. Eaton and J. H. Keefe (eds), Employment Dispute Resolution and Worker Rights in the Changing Workplace. Champaign, IL: Industrial Relations Research Association, 95-135.

Boroff, K. E. and Lewin, D. 1997. “Loyalty, Voice, and Intent to Exit a Union Firm: A Conceptual and Empirical Analysis." Industrial and Labor Relations Review, 51(1): 50-63.

Boswell, W. R. and Olson-Buchanan, J. B. 2004. “Experiencing Mistreatment at Work: The Role of Grievance-Filing, Nature of Mistreatment, and Employee Withdrawal." Academy of Management Journal, 47: 129-39.

Bronfenbrenner, K. 1997. "The Role of Union Strategies in NLRB Certification Elections." Industrial and Labor Relations Review, 50(2): 195-212.

Clermont, K. M. and Schwab, S. J. 2004. "How Employment Discrimination Plaintiffs Fare in Federal Court." Journal of Empirical Legal Studies, 1(2): 429-58. 
Colquitt, J. A. 2001. “On the Dimensionality of Organizational Justice: A Construct Validation of a Measure." Journal of Applied Psychology, 86: 386-400.

Colvin, A. J. S. 2003a. "Institutional Pressures, Human Resource Strategies, and the Rise of Nonunion Dispute Resolution Procedures." Industrial and Labor Relations Review, 56(3):375-92.

Colvin, A. J. S. 2003b. "The Dual Transformation of Workplace Dispute Resolution." Industrial Relations, 42(4): 712-35.

Colvin, A. J. S. 2004a. "Adoption and Use of Dispute Resolution Procedures in the Nonunion Workplace." In D. Lewin and B. E. Kaufman (eds), Advances in Industrial and Labor Relations, vol.13. Bingley, UK: Emerald, 69-95.

Colvin, A. J. S. 2004b. "The Relationship between Employee Involvement and Workplace Dispute Resolution." Relations Industrielles [Industrial Relations], 59(4): 671-94.

Colvin, A. J. S. 2006. "Flexibility and Fairness in Liberal Market Economies: The Comparative Impact of the Legal Environment and High Performance Work Systems." British Journal of Industrial Relations, 44(1): 73-97.

Colvin, A. J. S. 2007. “Empirical Research on Employment Arbitration: Clarity amidst the Sound and Fury?" Employee Rights and Employment Policy Journal, 11(2): 405-47.

Colvin, A. J. S. 2012. "American Workplace Dispute Resolution in the Individual Rights Era." International Journal of Human Resource Management, 23(3): 459-75.

Colvin, A. J. S. 2013. "Participation versus Procedures in Non-union Dispute Resolution." Industrial Relations, 52(Suppl. 1): 259-83.

Colvin, A. J. S. and Darbishire, O. R. 2012. “International Employment Relations: The Impact of Varieties of Capitalism." In G. Stahl et al. (eds), Handbook of International Human Resource Management Research. 3rd edn. Cheltenham, UK: Edward Elgar, Ch. 4, 52-75. 
Colvin, A. J. S., Klaas, B., and Mahony, D. 2006. "Research on Alternative Dispute Resolution Procedures." In D. Lewin (ed.), Contemporary Issues in Employment Relations. Champaign, IL: Labor and Employment Relations Association, Ch. 4, 103-47.

Cooper, L. J., Nolan, D. R., and Bales, R. A. 2000. ADR in the Workplace. St. Paul, MN: West Group.

Delaney, J. T., Lewin, D., and Ichniowski, C. 1989. Human Resource Policies and Practices in American Firms, BLMR \#137. Washington, DC: US Department of Labor.

Dix, G., Sisson, K., and Forth, J. 2009. "Conflict at Work: The Changing Pattern of Disputes." In W. Brown et al. (eds), The Evolution of the Modern Workplace. Cambridge, UK: Cambridge University Press, Ch. 8.

Doherty, L. and Teague, P. 2011. “Conflict Management Systems in Subsidiaries of Non- Union Multinational Organizations Located in the Republic of Ireland." International Journal of Human Resource Management, 22(1): 57-71.

Edelman, L. B. 1990. “Legal Environments and Organizational Governance: The Expansion of Due Process in the American Workplace." American Journal of Sociology, 95(6): 1401-40.

Edelman, L. B., Abraham, S. E., and Erlanger, H. S. 1992. "Professional Construction of Law: The Inflated Threat of Wrongful Discharge." Law and Society Review, 26(1): 47-83.

Edelman, L. B., Uggen, C., and Erlanger, H. S. 1999. "The Endogeneity of Legal Regulation: Grievance Procedures as Rational Myth." American Journal of Sociology, 105(2): 406-54.

Eisenberg, T. and Schlanger, M. 2003. "The Reliability of the Administrative Office of the U.S. Courts Database: An Initial Empirical Analysis." Notre Dame Law Review, 78: 1455-96.

Ewing, D. W. 1989. Justice on the Job: Resolving Grievances in the Nonunion Workplace. Boston, MA: Harvard Business School Press. 
Feuille, P. and Chachere, D. T. 1995. "Looking Fair or Being Fair: Remedial Voice Procedures in Nonunion Workplaces." Journal of Management, 21(1): 27-42.

Feuille, P. and Delaney, J.T. 1992. "The Individual Pursuit of Organizational Justice: Grievance Procedures in Nonunion Workplaces." In G. R. Ferris and K. M. Rowland (eds), Research in Personnel and Human Resource Management. Stamford, CT: JAI Press, 187-232.

Folger, R. and Cropanzano, R. 1998. Organizational Justice and Human Resource Management. Thousand Oaks, CA: Sage.

Freeman, R. B. and Medoff, J. L. 1984. What Do Unions Do? New York: Basic Books.

General Accounting Office 1997. Alternative Dispute Resolution: Employers' Experiences with ADR in the Workplace, GAO/GGD-97-157 ADR in the Workplace. Washington, DC: GAO.

Gibbons, M. 2007. Better Dispute Resolution: A Review of Employment Dispute Resolution in Great Britain. London: Department of Trade and Industry, HMSO.

Godard, J. 2003. “Do Labor Laws Matter? The Density Decline and Convergence Thesis Revisited." Industrial Relations, 42(3): 458-92.

Hall, P. and Soskice, D. (eds) 2001. Varieties of Capitalism: The Institutional Foundations of Comparative Advantage. Oxford: Oxford University Press.

Harris, L., Tuckman, A., and Snook, J. 2012. "Supporting Workplace Dispute Resolution in Smaller Businesses: Policy Perspectives and Operational Realities." International Journal of Human Resource Management, 23(3): 607-23.

Hirschman, A. O. 1970. Exit, Voice, and Loyalty. Cambridge, MA: Harvard University Press.

Huselid, M. A. 1995. "The Impact of Human Resource Management Practices on Turnover, Productivity, and Corporate Financial Performance." Academy of Management Journal, 38(3): 635-72. 
Klaas, B. S. and DeNisi, A. S. 1989. "Managerial Reactions to Employee Dissent: The Impact of Grievance Activity on Performance Ratings." Academy of Management Journal, 32(4): 705-18.

Kochan, T. A., Katz, H. C., and McKersie, R. B. 1994. The Transformation of American Industrial Relations. Ithaca, NY: ILR Press.

Kolb, D. M. 1987. “Corporate Ombudsman and Organization Conflict Resolution." Journal of Conflict Resolution, 31(4): 673-91.

Lewin, D. 1987. “Conflict Resolution in the Nonunion Firm: A Theoretical and Empirical Analysis." Journal of Conflict Resolution, 31(3): 465-502.

Lewin, D. 1990. “Grievance Procedures in Nonunion Workplaces: An Empirical Analysis of Usage, Dynamics, and Outcomes." Chicago-Kent Law Review, 66(3): 823-44.

Lewin, D. 2008. "Employee Voice and Mutual Gains," Proceedings of the 60th Annual Meeting of the Labor and Employment Relations Association (LERA), Jan., New Orleans, LA: 61-83.

Lewin, D. and Peterson, R. B. 1999. "Behavioral Outcomes of Grievance Activity." Industrial Relations, 38(4): 554-76.

Lipsky, D. B., Seeber, R. L., and Fincher, R. D. 2003. Emerging Systems for Managing Workplace Conflict. San Francisco, CA: Jossey-Bass.

Olson-Buchanan, J. B. 1996. "Voicing Discontent: What Happens to the Grievance Filer after the Grievance?" Journal of Applied Psychology, 81(1): 52-63.

Oppenheimer, D. B. 2003. "Verdicts Matter: An Empirical Study of California Employment Discrimination and Wrongful Discharge Jury Verdicts Reveals Low Success Rates for Women and Minorities," UC Davis Law Review, 37: 535-49.

Rees, D. I. 1991. "Grievance Procedure Strength and Teacher Quits." Industrial and Labor Relations Review, 45(1): 31-43. 
Roche, W. K. and Teague, P. 2012. "Human Resource Management and ADR Practices in Ireland." International Journal of Human Resource Management, 23(3): 528-49.

Sheppard, B. H., Lewicki, R. J., and Minton, J. W. 1992. Organizational Justice: The Search for Fairness in the Workplace. New York: Macmillan.

Stone, K. V. W. 1999. "Employment Arbitration under the Federal Arbitration Act." In A. E. Eaton and J. H. Keefe (eds), Employment Dispute Resolution and Worker Rights in the Changing Workplace. Champaign, IL: Industrial Relations Research Association, Ch. 2, 27-65.

Sutton, J. R. and Dobbin, F. 1996. "The Two Faces of Governance: Responses to Legal Uncertainty in U.S. Firms, 1955 to 1985." American Sociological Review, 61(5): 794-811.

Sutton, J. R., Dobbin, F., Meyer, J., and Scott, W. R. 1994. "The Legalization of the Workplace." American Journal of Sociology, 99(4): 944-71.

Westin, A. F. and Felieu, A. G. 1988. Resolving Employment Disputes without Litigation. Washington, DC: Bureau of National Affairs.

Wheeler, H. N., Klaas, B. S., and Mahony, D. M. 2004. Workplace Justice without Unions. Kalamazoo, MI: Upjohn Institute. 